Oprach S., Sonnabend F., and Haghsheno, S. (2019). "The General Contractor Response to Platform Ecosystems." In: Proc. $27^{\text {th }}$ Annual Conference of the International. Group for Lean Construction (IGLC), Pasquire C. and Hamzeh F.R. (ed.), Dublin, Ireland, pp. 583-594. DOI: https://doi.org/10.24928/2019/0211. Available at: <www.iglc.net>.

\title{
THE GENERAL CONTRACTOR RESPONSE TO PLATFORM ECOSYSTEMS
}

\author{
Svenja Oprach ${ }^{1}$, Felix Sonnabend ${ }^{2}$, and Shervin Haghsheno ${ }^{3}$
}

\begin{abstract}
Platforms enable value-creating interactions between producers and customers by mediating between their users. Supported by digitization, platforms use large datasets and integrated production systems to enhance the customer and producer experience. The platform's business model is expanding in the economy as digitization increases. In the context of the completion of building projects producers and customers find themselves in a complex tender and order process. On the producer side, the aim is to use resources as efficiently as possible and on the customer side to process orders as efficiently as possible. Digital platforms offer the potential to simplify the interaction between producers and customers and challenge the status quo of the classical general contractor (GC) business. Therefore, this paper investigates the impact on GCs by analysing expert interviews regarding business model implications for GCs through the development and emergence of digital platforms.
\end{abstract}

\section{KEYWORDS}

Business model, digital platform, network effects, efficiencies

\section{INTRODUCTION}

"Firms that fail to create platforms and don't learn the new rules of strategy will be unable to compete for long" - with this statement van Alstyne et al. (2016) clarify which direction competition will take in the future.

Currently, van Alstyne and Parker (2017, p. 27) observe that platforms aggressively and disruptively penetrate existing markets - that is, platforms destroy existing structures and systems in the markets. The best-known examples of disruptive platforms are Airbnb in the hospitality and Uber in the transport industry. According to Parker et al. (2016, p. 2 f.), the networked business model is the driving force of the success behind the platforms. The networked business model is essentially based on supporting interdependent users in creating value by enabling direct interactions between them. According to Amit and Zott (2001, p. 495), this business model increasingly replaces traditional brokers of products and services. Parker et al. warn that basically any industry can be the target of these disruptive platforms. Especially chaotic and fragmented markets are prone to be disrupted by platforms (Choudary, 2017b). 
With regard to the construction industry, Koskela (1992, p. 4) describes the existing fragmentation of work as the biggest problem. This places the construction industry directly in the focus of the platforms. For the construction industry, Alhava et al. (2017, p. 575) therefore predict a disruptive process in two steps:

1. Efficient companies will replace inefficient companies.

2. Networked business models will replace traditional business models.

In the long-term, as seen in other industries, competition will no longer take place between products, services and processes, but between business models (Gassmann et al. 2017; Choudary et al. 2013). Therefore companies will need to focus on the development of business models to stay competitive in the future (Pekuri 2015, p. 48; Chesbrough 2007, p. 12). Gassmann et al. (2017) even see this as an additional potential for innovation, which in many industries has not yet been tapped.

\section{LITERATURE OVERVIEW}

The broad interest for business models just started around the turn of the millennium with the internet emerging (Teece 2010, p. 174; Morris et al. 2005, p. 727). Also, the first scientific paper regarding platforms was published in that period. In 2003 Rochet and Tirole investigated the business models of companies from the telecommunication industry and with their findings shaped the concept of the platform business model.

Despite the developments in other industries, within the construction industry Pekuri et al. (2013) state that business models receive too little attention. As a result, Pekuri published four publications by 2015. There he examines the understanding of managers in the construction industry regarding the concept of business models and shows how business models can be used to analyze and control the value added in construction companies. He also dealt with the role of business models in the selection of projects and the lean transformation of companies in the construction industry.

Laine et al. put forward the first publication that links construction, business models and platforms in 2017. They describe the failure of classical business models and the potential of digital platforms in the construction industry. However, they also find that their results need to be tested. Alhava et al. (2017) published the next article on platforms in the construction industry in the same year. Their aim is to highlight the differences between network and traditional business models and the maturity of business models in the construction industry. They come to the conclusion that business models in the construction industry follow traditional patterns and therefore there is a great potential for disruption. Consequently, they call on the players in the construction industry to promote the development of their business models. They also recommend developing digital platform within the construction industry before aggressive forces outside the market bring about disruptive change.

\section{RESEARCH OBJECTIVE}

Building on the work of Laine et al. (2017) and Alhava et al. (2017) this paper investigates the implications of digital platforms and the reaction of GCs. The general contractor was chosen because they are filling the role of the classic intermediaries for services and information in the construction industry (Laine et al. 2017, p. 177). They match the demand 
of the client with the competences of subcontractors, but don't allow any direct interactions between them. Therefore, they are particularly at risk of being subject to competition from networked business models. In order to thrive in future competition, general contractors must therefore address networked business models to develop knowledge and a strategy themselves. The aim of this research therefore is to evaluate the challenges and opportunities of digital platforms and the new business models for the GC to formulate recommendations for action. In order to do so, three major research questions are addressed:

1. How is the understanding of the concept of business models in the construction industry?

2. What is the status quo business model of the GC in the German market?

3. What are the potentials and challenges concerning platforms in the construction industry?

\section{METHOD}

Data was collected through seven interviews with industry experts from the German construction market. The experts were selected focusing on their role and market understanding. The interviewees have different professional backgrounds from project control, consulting, GC and client construction department. It is important to mention, that this sample does not consist of all the stakeholders of a construction project - i.e. planers, subcontractors and authorities were not interviewed.

The interview partners (IP) are employed in roles from a construction manager to a CEO level. The average work experience is above 15 years (15,71 years). The first contact was established via email. The interview itself was conducted in person or via Skype. Since the amount of available data for the underlying question is very low, the aim is to give a first orientation in the field. Therefore the authors decided to focus on explorative and speculative interviews to gather opinions and interpretations of the experts.

Table 1 provides and overview of the interview structure. Following the research questions, the interviews was divided in three main sections, (A) Understanding of Business Models in the Construction Industry, (B) the Business Model of GCs and (C) Potentials of digital platforms in the construction industry. Every section is divided into categories. This enabled the authors to analyse and compare the data in a matrix. For the evaluation of the expert interviews the authors applied a qualitative content analysis. For this the statements of the experts were assigned to one of the categories. The categories for Section A and B have been developed deductively, whereas the categories for Section C were developed inductively. To set a common data base and understanding of the concept of business models, in section B the business model of a GC was put together collaboratively using the Business Model Canvas (BMC) developed by Osterwalder and Pigneur (2011). According to them a business model defines the logic of how a company creates, delivers and captures value. In order to create a framework to enable structured communication and analysis of business models, they created the BMC, which consists of nine elements to describe the underlying business model of a company. 
Table 1: Interview structure

\begin{tabular}{|c|c|c|}
\hline NR. & CATGEGORY & DEFINITION \\
\hline \multicolumn{3}{|c|}{ SECTION A: UNDERSTANDING OF BUSINESS MODELS IN CONSTRUCTION } \\
\hline A.1 & Experience & Experience gained through working career \\
\hline A.2 & Association & Free thoughts in regard to business models \\
\hline A.3 & Elements & Elements of business models \\
\hline A.4 & Function & Function of business models \\
\hline \multicolumn{3}{|c|}{ SECTION B: GC'S BUSINESS MODEL } \\
\hline B.1 & Customer segments & \multirow{9}{*}{$\begin{array}{l}\text { Elements that define a business model } \\
\text { according to the Business Model Canvas } \\
\text { framework of Osterwalder and Pigneur } \\
\text { (2011). }\end{array}$} \\
\hline B.2 & Value Proposition & \\
\hline B.3 & Channels & \\
\hline B.4 & Customer relationships & \\
\hline B.5 & Revenue stream & \\
\hline B.6 & Key resources & \\
\hline B.7 & Key activities & \\
\hline B.8 & Key partner & \\
\hline B.9 & Cost structure & \\
\hline \multicolumn{3}{|c|}{ SECTION C: POTENTIAL OF DIGITAL PLATFORMS IN CONSTRUCTION } \\
\hline C.1 & Potentials for building industry & Digital platform incentives for the industry \\
\hline C.2 & Potentials for companies & Digital platform incentives for companies \\
\hline C.3 & Potentials for clients & Digital platform incentives for clients \\
\hline C.4 & Requirements & $\begin{array}{l}\text { Special requirements regarding the } \\
\text { construction industry }\end{array}$ \\
\hline C.5 & Risks for GCs & Risk for displacement by digital platforms \\
\hline
\end{tabular}

\section{RESULTS}

\section{SECTION A - Understanding OF Business Models in CONSTRUCTION}

As already seen by Pekuri et al (2013, p. 9), Section A put forward the thesis that there is no common understanding of the concept of business models in the construction industry. In their interviews, they found that managers in the construction industry claim to have an understanding of business models. However, they also found out that each of these managers has their own understanding of the concept of business models. The interviews with experts conducted in the context of this work confirm this finding.

\section{Section B - The Business Model of The General Constructor}

The results of the evaluation of Section B are shown in figure 1. As described by Laine et al. (2017) the GCs business model follows a linear logic (pipes). Value is created 
upstream and consumed downstream. According to the interview partners, the main value proposition of GCs is to reduce the complexity of the building project. Additionally, they take over the risks in terms of time, costs and quality. Through value engineering GCs also offer the customer optimized solutions.

Figure 1 shows, that in order to compete in their market, the emphasis of the GCs business model is on the price. Consequently the GCs focus is to reduce cost to achieve cost leadership in the market. In the logic of the GC business model this is achieved through project specific procurement of capacities. This way they ensure, that their internal resources are fully occupied. To realize better prices, GCs trie avoid direct competition and try to receive orders directly, i.e. in the form of follow-up projects. Nevertheless, the core business of GCs seem linear, their structure and organisation show characteristics of a network business model. One of the key resources of the GC's business is their network regarding subcontractors and supply chain, but since this network is not transparent to the client, GCs act as inefficient gatekeepers.

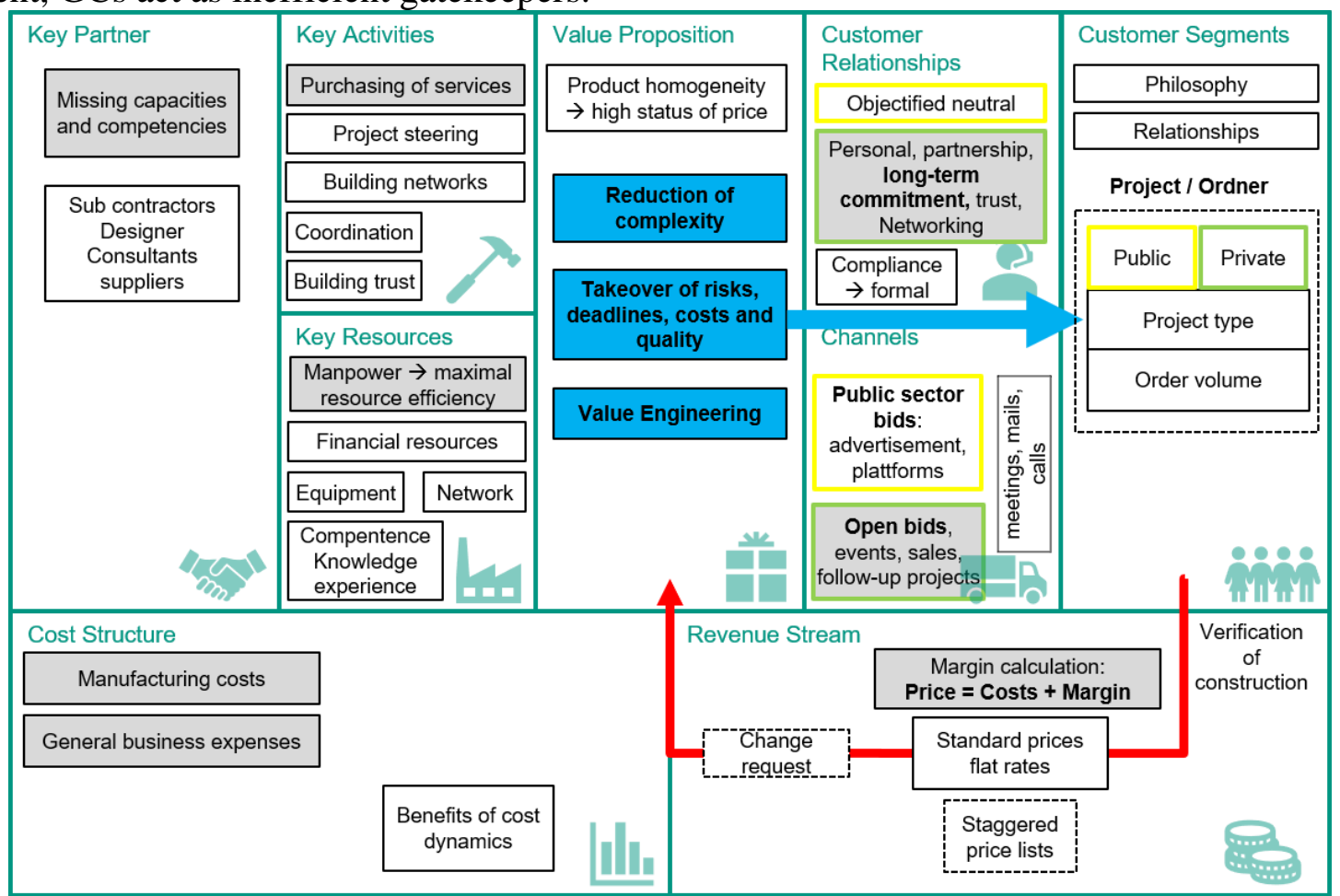

Figure 1: GC's business model based on BMC

\section{Section C - Potentials of Digital Platform in Construction}

In Section $\mathrm{C}$ all the findings regarding the potentials of digital platforms within the construction industry was gathered. As potential users of the platform all IP name the clients on the tendering side and a selection of project participants on the bidding side. In the interviews, the experts were asked about the potential of a digital platform in their own environment. The potentials for the construction industry, construction companies and owners were queried in detail. The categorisation of the statements by means of qualitative 
content analysis led to two central approaches: potentials with regard to tendering and awarding of contracts and potentials with regard to the provision of a production system.

The potential of a digital platform in the construction industry for the processes of tendering and awarding contracts is mentioned by all interview partner. This potential is closely related to the key activity of digital platforms to connect and enable interaction between the users.

IP 5 states that contracting authorities can benefit in particular from the standardisation of tender documents. This makes it easier and faster to compare offers. IP 7 also claims that through standardisation digital platforms can save clients time in research and competition enquiries and thus directly save costs. IP 1 sees the greatest potential for clients in the evaluation of contractors. He claims that every company on the platform is interested in positive evaluations and therefore, in addition to saving time, a general increase in quality can be expected. IP 2 also sees great potential for builders in evaluation systems. In his opinion, a transparent evaluation system creates a self-levelling system that drives performance and quality and thus added value for the customer. Furthermore, he explains that building owners can make faster and better decisions, because the system allows to distinguish more easily between good and bad contractors. IP 1 therefore not only sees an increase in quality, but also a decreased time span for clients to place an order. According to IP 3, providing a simple way of commissioning high-quality companies saves costs. IP 4 , on the other hand, sees the benefit for clients not only in the reduction of their own costs for processing tenders, bids and awarding contracts, but in the reduction of the bid price. He justifies this through the fact that with transparency and evaluation systems, the competition between contractors will become more professional and pressure on cost leadership increases further.

According to IP 5, the other side of the platform - the bidding side - also benefits from standardisation. For companies, the transparency of the required documents makes the bid preparation process easier. This gives them additional security when bidding. According to IP 7, companies can thus acquire orders more quickly. But evaluation systems also have advantages for the bidding companies on the platform. For example, IP 1 explains that the evaluation of building owners can give entrepreneurs information about their payment loyalty. IP 2 also claims that evaluation systems reduce the relevance of the size of businesses and make smaller businesses more competitive. Platforms therefore give small businesses a fair chance to win more contracts for good performance. Instead of good performance, IP 1 speaks of competition over quality. IP 3 also sees evaluation systems as a potential for companies and in this respect continues to argue that evaluation systems also make it possible to take soft skills into account when awarding contracts. Additionally, IP 3 sees the possibility for companies to show their presence on the platform and use it for marketing purposes.

At this point it must also be noted that four of the seven interview partners take a critical view on evaluation systems. IP 3, for example, warns about paid (unregular) evaluations. The IP thus draws attention to the fact that mechanisms have already been developed in existing digital platforms to manipulate rating systems. IP 7 also questions the significance of rating systems. He justifies this with the danger that rating systems can be leveraged by collusion. As an example, he cites an entrepreneur who waives a certain supplementary 
sum for a positive rating. IP 5 also questions which criteria are used for the evaluation or selection. He doubts the potential of evaluation systems and questions their significance analogous to IP 3 and IP 7 with regard to manipulation possibilities. He sees references from resilient sources as an approach for a reliable rating system. IP 7 considers the same approach necessary for an evaluation system in the construction industry. In his opinion, a rating system can only work if it is objective, fair, transparent, reliable and not anonymous. IP 4 also highlights the benefits of rating systems in question. In his opinion, in the end the cheapest alternative is chosen and quality is neglected. He therefore fears that competition for the best price will become tougher for companies, but that customers will be rewarded with lower prices.

Four of the seven experts see the potential of a digital platform to set up a production system for its users. IP 2 stresses that the coupling of users to the platform alone is not enough. Furthermore, according to him, the digital platform must coordinate its users by providing them with a production system. The setting up of a production system is closely related to the key activity of platforms to reduce resistance in interactions.

Three of the seven IPs explain that the benefits for users of providing a production system through a digital platform lie in particular in the standardisation of service delivery processes. IP 1 explains in more detail that digital platforms provide transparency because they require simple and clearly defined processes. He explains that there is no room for interpretation within digital platforms, as in the digital world only true and false can be distinguished.

For service providers, this means that they are given transparency over the building owners planning and decision-making processes. According to IP 1, the resulting common understanding of the processes and procedures ultimately leads to service providers being able to work more efficiently - thus optimising their value-added process. IP 7 adds that process transparency helps to eliminate uncertainties and allow providers to set deadlines early. This means that vendors can better schedule their resources and use them more efficiently. In this context, IP 7 is designing the vision of a product configurator on the part of the building owners - similar to the one used by the automotive industry for the individual configuration of vehicles. In his opinion, such a product configurator in combination with other technology can be used to create a virtual experience of the end product. In addition to the purely visual experience the configurator also provides information on price and dates based on stored standard processes and data. This improves the decision-making basis for building owners.

IP 5 and IP 6 also see a special added value for the users in the integrated handling of the project in the production system of the digital platform. This shortens information paths and makes data more accessible. Users can access all data regarding costs, deadlines and qualities over the entire life cycle of the property. According to IP 7, the collected data will enable the foresighted generation of information on prices, construction processes and deadlines. According to IP 6, the data can be used directly during the project to map the effects of changes on deadlines and construction processes in real time. Looking back, IP 5 also sees the possibility of cost monitoring and controlling by connecting the platform to a platform on the client side. IP 7 also states that, similar to the commissioning of general contractors, building owners have a central contact person via the platform. Four of the 
seven IP explicitly see a potential for digital platforms in the construction industry in the support of communication. According to IP 7, clear communication can be achieved with a digital platform. According to IP 3, the usual tactics in meetings to optimise one's own interests can be prevented. In this regard, like IP 5, he mentions digital project rooms in particular, in which a project file with access rights for all participants exists. This reduces information asymmetries and builds trust.

\section{Section C - Challenges of Digital Platforms in Construction}

In addition to the potentials, all IP also see special characteristics and obstacles in connection with the development of a digital platform for the construction industry. According to IP 7, the characteristics of the construction industry in particular pose challenges for the implementation of a digital platform. In his opinion, the characteristics of the building industry strongly differentiate it from other industries in which digital platforms have already established themselves. Some of these characteristics will be examined in more detail below. The potential to achieve a common understanding of the product and the processes is critically questioned by IP 1 with regard to the high complexity in the construction industry. IP 5 and IP 7 also see complexity as a challenge for the development of a digital platform for the construction industry. According to IP 5 and IP 7 , the high level of complexity is accompanied by the usually high investment sums for construction products. According to IP 7, this leads to long financing terms in the construction industry. He therefore believes that the value of products also plays a more decisive role in the construction industry than in other sectors. IP 5 cites an analogy to Amazon in this context. An error in an order at Amazon usually has no consequences due to a customer-friendly right of return. However, a building in which an error is made in the order cannot simply be returned without consequences. This analogy is linked to another characteristic of the building industry, which IP 7 regards as a challenge for the development of digital platforms: In the construction industry there are construction contracts for each project. This means that each product is a prototype. IP 7 explains that the constant production of unique products hinders the learning curve in terms of process efficiency. He compares the automotive industry with the construction industry and finds that the automotive industry also needs several years to produce its prototypes. However, as soon as they manufacture the products in series, the learning curve leads to an enormous increase in efficiency. This extreme learning curve, which is also based on standardization, cannot be achieved in this way by the engineer-to-order oriented construction industry. IP 7 also explains that disturbances are always to be expected in construction projects. In addition to the complexity, this is due to the fact that production takes place on site. Because of the disruptions, he believes that a high level of social competence is always necessary to solve problems in construction projects. Similarly, IP 6 states that the basic prerequisite for a digital platform in the construction industry is human monitoring. This has to identify problems and risks and communicate them, especially during the construction phase. According to IP 1, IP 4 and IP 7, a special degree of trust is also necessary, particularly because of the high investment volume. IP 1 and IP 7 consider the establishment of trust between the users of the platform (client and project participants) to be particularly necessary. IP 4 also emphasises that users should also be able to trust the 
platform with regard its liability. In contrast to IP 1, IP 4 and IP 7 rating systems take a critical view of building trust.

In addition, there are still a number of challenges with regard to legal issues. IP 3 and IP 6, for example, mention the Federal Procurement Act. This obliges contracting

\begin{tabular}{|c|c|c|c|c|c|}
\hline & \multirow[t]{2}{*}{ Status Quo - GC } & \multicolumn{2}{|c|}{ Potential for digital platforms in the construction industry } & \multirow{2}{*}{$\begin{array}{l}\text { Challenges for digital platforms } \\
\text { in the construction industry }\end{array}$} & \multirow[t]{2}{*}{ Recommended action for GC } \\
\hline & & Tender, award, contract & Provision of a production system & & \\
\hline 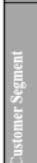 & $\begin{array}{l}\text { Professional client who wants to } \\
\text { realize complex projects } \\
\text { order / project specific } \\
\text { categorization: } \\
\text { Public / private } \\
\text { Project content / industry } \\
\text { project scope } \\
\text { Farther: } \\
\text { Basic philosophy / relationships }\end{array}$ & & & & $\begin{array}{l}\text { Consciously perceive that both the } \\
\text { client and the key partners from } \\
\text { the status quo represent customers. } \\
\text { Definition of the sides of the } \\
\text { platform (including preview of } \\
\text { potential sides). }\end{array}$ \\
\hline \begin{tabular}{|l}
$\frac{5}{2}$ \\
$\frac{2}{2}$ \\
$\frac{2}{2}$ \\
\end{tabular} & $\begin{array}{l}\text { Reduction of complexity. } \\
\text { Taking risks for deadlines, costs } \\
\text { and qualities. } \\
\text { Value engineering. } \\
\text { Value offer is perceived very } \\
\text { homogeneously by the customers, } \\
\text { therefore the significance of the } \\
\text { price is high. }\end{array}$ & Enable direct interaction & Simplify direct interactions & & $\begin{array}{l}\text { Focus on enabling direct } \\
\text { interaction between users. Start } \\
\text { with the tendering, assignment and } \\
\text { order rpocesses creating the basis } \\
\text { for further interactions. Value } \\
\text { offerings from the status quo of the } \\
\text { GC are taken over, but must be } \\
\text { reinterpreted ( elimination of } \\
\text { friction by providing a production } \\
\text { system). }\end{array}$ \\
\hline है & $\begin{array}{l}\text { Public client: } \\
\text { Public tenders, submission of } \\
\text { tenders, placing of orders (open } \\
\text { and transparent competition } \\
\text { according to VOB). } \\
\text { Private client: } \\
\text { Classic sales work: building } \\
\text { relationshiphs, maintaining } \\
\text { networks, organizing events. } \\
\text { Follow-up contracts. } \\
\text { After placing the order, } \\
\text { communicate via regular meetings, } \\
\text { e-mail traffic and telephone calls. }\end{array}$ & Order brokerage via platform & $\begin{array}{l}\text { Integral handling on platform: } \\
\text { Platform as digital project space is } \\
\text { central processing point } \rightarrow \text { Short } \\
\text { information paths. } \\
\text { Throughout the lifecycle there is } \\
\text { the possibility to access all data of } \\
\text { the building in terms of cost, } \\
\text { deadline qualities } \rightarrow \text { Predictive, } \\
\text { real-time and retrospective } \\
\text { planning and control of costs and } \\
\text { deadlines. }\end{array}$ & $\begin{array}{l}\text { Disruptions are unplanned and can } \\
\text { not be predicted. } \\
\text { Legal Challenges in the award of } \\
\text { public services. }\end{array}$ & $\begin{array}{l}\text { Open channels and drop } \\
\text { gatekeeper function. Define role as } \\
\text { mediator. Enable the collection of } \\
\text { data } \rightarrow \text { key ressourcess } \\
\text { Initially exclude public clients. }\end{array}$ \\
\hline 部 & $\begin{array}{l}\text { Public client: } \\
\text { formal and neutral. } \\
\text { Private client: } \\
\text { Shaped by personal cooperation, } \\
\text { partnerships, long-term } \\
\text { relationships, building trust. } \\
\text { Formality due to compliance } \\
\text { regulations. }\end{array}$ & \begin{tabular}{|l|} 
Rating Systems: \\
Create transparency and trust. \\
Simple decision-making basis for \\
builders. \\
Clients processes become more \\
time and cost efficient. \\
Orders are awarded at lower asking \\
prices but with better quality. \\
Information about payment loyalty. \\
Increase the competitiveness of \\
smaller businesses. \\
Competition over quality. \\
Consideration of soft skills at \\
assignment.
\end{tabular} & & $\begin{array}{l}\text { Due to the high level of } \\
\text { investment, a particularly high } \\
\text { degree of trust is necessary. } \\
\text { Users must trust ach other but } \\
\text { also trust the platform itself to be } \\
\text { responsible. } \\
\text { Rating systems do not create } \\
\text { enough confidence because they } \\
\text { are susceptible to manipulation. } \\
\text { Construction projects require a } \\
\text { high level of social competence to } \\
\text { solve problems. } \\
\text { Human surveillance is a } \\
\text { prerequisite. } \\
\text { A new kind of contract becomes } \\
\text { necessary. }\end{array}$ & $\begin{array}{l}\text { Become aware that the focus is in } \\
\text { developing community. Rethinking } \\
\text { from acquisition of projects to } \\
\text { acquisition of users. Strong control } \\
\text { of the offered service by the } \\
\text { platform operator. } \\
\text { For example, regular on-site } \\
\text { inspections of specially trained } \\
\text { staff of the platform ( } \rightarrow \text { key } \\
\text { resources). Build the rating system } \\
\text { on references from reliable } \\
\text { sources. } \\
\text { Ensure liability of the platform } \\
\text { through banks and insurance } \\
\text { companies }(\rightarrow \text { key partner). if } \\
\text { applicable with own fortune. } \\
\text { Maintain human component. } \\
\text { Specialists take care of problem } \\
\text { solving in conflict situations. } \\
\text { Establish contracts for users of the } \\
\text { platform in the form of codes of } \\
\text { conduct. Implement intensive } \\
\text { feedback loops to evaluate these } \\
\text { rules. }\end{array}$ \\
\hline 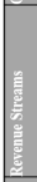 & $\begin{array}{l}\text { Source of income: client. } \\
\text { Price: Cost plus surcharge. } \\
\text { Revenues: after proof of } \\
\text { performance. }\end{array}$ & & & $\begin{array}{l}\text { High investment volume for the } \\
\text { products. }\end{array}$ & $\begin{array}{l}\text { Start with small orders or partial } \\
\text { orders. } \\
\text { Plan the monetization strategy: } \\
\text { Potential source of income; all } \\
\text { sides. } \\
\text { Price: Define price level and price } \\
\text { structure according to the added } \\
\text { value for each page. } \\
\text { Revenue streams transaction- } \\
\text { dependent and / or independent. } \\
\end{array}$ \\
\hline$\frac{8}{8}$ & $\begin{array}{l}\text { Staff } \rightarrow \text { Focus on maximum } \\
\text { utilization } \\
\text { equipment } \\
\text { network } \\
\text { Competence, knowledge, } \\
\text { experience, knources } \\
\text { Financial ressources }\end{array}$ & & & & $\begin{array}{l}\text { Retrain specialists staff. } \\
\text { Make expertise, knowledge and } \\
\text { experience available in the form of } \\
\text { data for the platform. } \\
\text { Tap existing networks and make } \\
\text { them available for the platform. } \\
\text { Development of the technical } \\
\text { infrastructure. }\end{array}$ \\
\hline$\frac{2}{2}$ & $\begin{array}{l}\text { Purchase of service } \\
\text { Building networks } \\
\text { Building trust } \\
\text { coordination } \\
\text { project management }\end{array}$ & \begin{tabular}{|l|} 
Standardization: \\
Offers become more comparable. \\
Building owner processes become \\
more time and cost efficient. \\
Transparency and understanding of \\
documents to be submitted and \\
evidence of offer. \\
Creation of offers is simplified. \\
Acquisition of orders becomes \\
more time and cost efficient. \\
\\
\end{tabular} & $\begin{array}{l}\text { Standardization: } \\
\text { Product configurator enables } \\
\text { virtual experience of the product } \\
\text { and provides real-time information } \\
\text { f about costs and deadlines. } \\
\text { Creating a common understanding } \\
\text { as builders, planning and decision- } \\
\text { making processes become more } \\
\text { transparent. } \\
\text { Appointments can be fixed early. } \\
\text { This eliminates uncertainties and } \\
\text { resources can be optimally } \\
\text { planned. More efficient work is } \\
\text { possible. }\end{array}$ & $\begin{array}{l}\text { Due to the high complexity of the } \\
\text { construction industry, a common } \\
\text { understanding is questionable. } \\
\text { The peculiarity of the construction } \\
\text { industry is that tevery building is a } \\
\text { prototype. Standards for unique } \\
\text { items are only possible on an } \\
\text { abstract level. } \\
\text { Construction processes are } \\
\text { exposed to external disturbances } \\
\text { that can not be controlled and } \\
\text { planned. }\end{array}$ & $\begin{array}{l}\text { Start with standardization of } \\
\text { tendering, assignment and order } \\
\text { processes. } \\
\text { Gradual standardization of } \\
\text { planning and execution processes } \\
\text { from simple to highly complex } \\
\text { processes. Clear definition of the } \\
\text { interfaces. } \\
\text { Excessive data collection. } \\
\text { Implement feedback loops to } \\
\text { evaluate and optimize the } \\
\text { standardized processes. }\end{array}$ \\
\hline E & $\begin{array}{l}\text { Acquisition of missing capacities } \\
\text { and competencies: } \\
\text { subcontractors } \\
\text { planners } \\
\text { consultants } \\
\text { Suppliers }\end{array}$ & & & & $\begin{array}{l}\text { Understand that key partners from } \\
\text { status quo in the platform represent } \\
\text { customers. } \\
\text { Winning partners with a focus on } \\
\text { reducing frictions in the } \\
\text { interactions. } \\
\text { For example: } \\
\text { Banks for financing. } \\
\text { Insurance for liability. } \\
\text { Authorities for qualification } \\
\text { certificates of companies. }\end{array}$ \\
\hline & $\begin{array}{l}\text { Cost of production } \\
\text { General business costs } \\
\text { Great momentum especially in the } \\
\text { manufacturing costs }\end{array}$ & & & & $\begin{array}{l}\text { Invest in acquisition of users and } \\
\text { development of technical } \\
\text { infrastructure. }\end{array}$ \\
\hline
\end{tabular}

Figure 2 - Recommended actions for GC 
authorities to publish in public media. This means that the potential of a digital platform in terms of tendering, awarding and contracting processes is initially not accessible to public developers. According to IP 2 and IP 5, cooperation in digital production systems on digital platforms continues to require a new type of contract. According to IP 2, the first approaches towards new contracts have already been made with Alliancing and the Integrated Form of Agreement.

\section{DISCUSSION}

The matrix in figure 2 links the findings of sections $\mathrm{B}$ and $\mathrm{C}$ and derives recommendations for actions. All results in this matrix are related to the BMC. The first column represents the starting point for the definition of the recommendations for action. It therefore reflects the status quo of the GC's business model (section B). The next two columns show the potentials with regard to tendering and awarding contracts as well as the provision of a production system (section $\mathrm{C}$ ). The potentials were also assigned to the elements of the BMC. For this purpose, the potentials were broken down into their approaches and assigned to the BMC elements. The next column shows the challenges that digital platforms will face in the construction industry (section $\mathrm{C}$ ). These are also assigned to the individual elements of the BMC, analogous to the potentials.

The recommendations for action for general contractors are derived from the status quo, the potentials, the obstacles and the general principles of networked business models. These recommendations are made for each element of the business model to develop the GC's business logic in the direction of networked business models. Based on this GCs can formulate concrete measures for the elements of their business models. This is the first step in transforming their business model towards a platform. It was found that there is potential for a digital platform in the construction industry, in particular with regard to the tendering and awarding of contracts and the provision of a production system. The added value of these potentials lie on the one hand in the fact that direct interactions are made possible and on the other hand in the fact that these are simplified. With these first potentials, the central value proposition behind the logic of the networked business models is implemented. The second potential focuses on the key activity of networked business models to reduce resistance. The potentials are based on three approaches: standardization of processes and documents, establishment of evaluation systems and integration of interdependent processes. In addition, the interviews have shown that challenges lie above all in the characteristics of the construction industry. The high complexity of building projects, which leads to high investment costs and therefore requires a special degree of trust, is to be emphasized in this connection.

\section{LIMITATIONS}

This research paper gives a first brief look into the GC's awareness of the challenges and transformations they face. In consideration of the fact that the underlying sample is limited to depicting a part of the German construction industry, further research and in-depth analysis are needed to gather more data and examine the impact on the GC's business model and their ability to adapt to the changing market conditions. 


\section{REFERENCES}

Alhava, Otto; Laine, E.; Kiviniemi, Arto (2017). „Construction Industry needs an Airbnb of its own!" ResearchGate.

van Alstyne, Marshall W.; Parker, Geoffrey G.; Choudary, Sangeet Paul (2016). „Pipelines, Platforms, and the New Rules of Strategy." Harvard Business Review.

van Alstyne, Marshall; Parker, Geoffrey (2017). „Platform Business: From Resources to Relationships." Platform Business 9(1), S. 24-30. DOI: 10.1515/gfkmir- 2017-0004.

Amit, Raphael; Zott, Christoph (2001). „Value creation in E-business." Strat. Mgmt. J. 22(6-7), S. 493-520. DOI: 10.1002/smj.187.

Chesbrough, Henry (2007). „Business model innovation: it's not just about technology anymore." Strategy \& Leadership 35(6), S. 12-17. DOI: 10.1108/10878570710833714.

Choudary, Sangeet Paul (2013). „Why Business Models Fail: Pipes vs. Platforms." WIRED. Available online at https://www.wired.com/insights/2013/10/why- businessmodels-fail-pipes-vs-platforms/, last checked on 07.02.2018.

Choudary, Sangeet Paul (2017b). „The future of competition Platform Strategy." Pipes to Platform. Available online at http://platformed.info/the-future-of- competition/, last checked on am 21.12.2017.

Gassmann, Oliver; Frankenberger, Karolin; Csik, Michaela (2017). „Geschäftsmodelle entwickeln: 55 innovative Konzepte mit dem St. Galler Business Model Navigator." Hanser, München.

Koskela, Lauri (1992). „Application of the new production philosophy to construction." Stanford University Press, Stanford.

Laine, Enni; Alhava, Otto; Peltokorpi, Antti; Seppänen, Olli (2017). „Platform Ecosystems: Unlocking the Subcontractors' Business Model Opportunities." 25th Annual Conference of the International Group for Lean Construction, S. 177-184. DOI: $10.24928 / 2017 / 0325$.

Morris, Michael; Schindehutte, Minet; Allen, Jeffrey (2005). „The entrepreneur's business model: toward a unified perspective." Journal of Business Research 58(6), S. 726-735. DOI: 10.1016/j.jbusres.2003.11.001.

Osterwalder, Alexander; Pigneur, Yves (2011). „Business Model Generation: A Handbook for Visionaries, Game Changers, and Challengers." Wiley.

Parker, Geoffrey; van Alstyne, Marshall W.; Choudary, Sangeet Paul (2016). „Platform Revolution: How Networked Markets are Transforming the Economy-and How to Make Them Work for You." Norton \& Company, New York.

Pekuri, Aki (2015). „The role of business models in construction business management." Universitatis Ouluensis.

Pekuri, Aki; Pekuri, Laura; Haapasalo, Harri (2013). „Business models in construction companies - construction managers' viewpoint." International Conference on Technology Innovation and Industrial Management TIIM2013.

Rochet, Jean-Charles; Tirole, Jean (2003). „Platform competition in two-sided markets." Journal of the european economic association 1(4), S. 990-1029.

Teece, David J. (2010). „Business Models, Business Strategy and Innovation." Long Range Planning 43(2-3), S. 172-194. DOI: 10.1016/j.lrp.2009.07.003. 
Oprach S., Sonnabend F., and Haghsheno, S

Proceedings IGLC - 27, July 2019, Dublin, Ireland 